\title{
Variable Influencing Parameters of Different Levels of Immunosuppression in HAART-naive HIV Subjects in Nigeria
}

\section{Ernest N Anyabolu*}

Department of Medicine, Imo State University Teaching Hospital, Orlu, Nigeria

*Corresponding author: Anyabolu EN, Department of Medicine, Imo State University Teaching Hospital, Orlu, Nigeria, Tel: 23408035090496; E-mail: enhealer@yahoo.com

Received date: June 26, 2017; Accepted date: July 12, 2017; Published date: July 14, 2017

Copyright: (C2017 Anyabolu EN. This is an open-access article distributed under the terms of the Creative Commons Attribution License, which permits unrestricted use, distribution, and reproduction in any medium, provided the original author and source are credited.

\begin{abstract}
Background and Objectives: Varying degrees of immunosuppression may be observed in human immunodeficiency virus (HIV) infected subjects. This study sought to evaluate the factors which might influence different levels of immunosuppression in this group of subjects.

Methodology: Immunosuppression, defined as CD4 $<500$ cells $/ \mathrm{ml}$, was evaluated in treatment-naïve HIV subjects. Body mass index (BMI), $24 \mathrm{~h}$ urine creatinine (24HUCr), $24 \mathrm{~h}$ urine protein (24HUP), creatinine clearance $(\mathrm{ClCr})$, hemoglobin $(\mathrm{Hb})$ and $\mathrm{CD} 4$ cells count were determined and the data compared among the subjects who have different levels of immunosuppression, defined here as mild for CD4 350-499 cells/ml, moderate for CD4 200-349 cells/ml and severe for CD4<200 cells/ml

Results: CD4 cells count $200-349 / \mathrm{ml}$ was prevalent in $31.3 \%$, CD4 350-499/ml in 25.4\% and CD4 $\geq 500$ cells/ml in $122(31.0 \%)$ of the HIV subjects. Immunosuppression was significantly associated with $B M I(d f=9, p=0.008)$, $24 \mathrm{HUCr}(\mathrm{df}=6, \mathrm{p}=0.019)$ and anemia $(\mathrm{df}=9, \mathrm{p}<0.001)$. None of these three variables, in addition to 24HUP, was a predictor of moderate immunosuppression (CD4 cells count 200-349/ml). However, BMI, ClCr, 24HUP and Hb were predictors of mild immunosuppression (CD4 350-499 cells $/ \mathrm{ml}) \quad(p=0.006, p=0.008, p=0.026$ and $p=0.003$ respectively).
\end{abstract}

Conclusion: Variable levels of immunosuppression were prevalent in this study. Anemia, abnormal weight and renal damage were common but variable in subjects who have different levels of immunosuppression in the early stage of HIV infection.

Keywords: Levels of immunosuppression; CD4 cells count; Anemia; Abnormal weight; Renal damage; HIV; Nigeria

\section{Introduction}

Immunosuppression is an ominous factor in HIV infection. Nigeria a Sub-Saharan African country, not only has a high prevalence of HIV infection but is also enmeshed in the web of problems inherent in late presentation of cases to healthcare centers [1]. As a result, HIV subjects may have developed some complications associated with disease progression, even on presentation $[2,3]$.

Disease activity and progression are mired by immunosuppression in HIV infection [4-7]. Studies have shown some factors which might influence immunosuppression in HIV subjects and non-HIV individuals. [8-11]. These factors include body mass index (BMI), demography, genetics, behavior and sex workers, among others [8-11]. A study has also demonstrated an association between low CD4 $(<200$ cells/ml) and BMI, serum low density lipoprotein cholesterol, anemia, $24 \mathrm{~h}$ urine protein, as well as creatinine clearance in treatment-naïve HIV subjects [8]. The advent of opportunistic infections and opportunistic malignancies are associated with immunosuppression in HIV infection $[2,3,6-8,12]$. There was a paucity of studies that assessed different levels of immunosuppression in HIV infected individuals. This study was carried out to determine the factors that might influence different levels of immunosuppression, adjudged by different levels of $<$ CD4 500 cells $/ \mathrm{ml}$, in the early stage of HIV infection.

\section{Materials and Methods}

In this cross-sectional study conducted in Federal Medical Centre, Owerri, Nigeria, in 2011, HIV-positive subjects were consecutively recruited. The hospital, a tertiary health institution, serves the state which has a population of about 3,927,563 [13].

Age range of 16-65 years and treatment-naïve HIV positive status were the inclusion criteria, whereas the exclusion criteria were adrenal disease, renal or terminal illnesses, malignancies and pregnancy. Each participant in this study gave informed written consent. The study was approved by the Ethics Committee of the hospital.

With the aid of a questionnaire, demographic and anthropometric data were collected from the subjects. Gender, age, place of origin and domicile of the subjects were obtained. BMI was determined as weight/ height ${ }^{2}\left(\mathrm{~kg} / \mathrm{m}^{2}\right)$.

Clear instructions were given to all the subjects on how to collect 24 $\mathrm{h}$ urine sample. For each participant, day-time blood samples and spot urine samples were collected at the end of the $24 \mathrm{~h}$ urine sample collection $[8,14-16]$. 
Citation: Anyabolu EN (2017) Variable Influencing Parameters of Different Levels of Immunosuppression in HAART-naive HIV Subjects in Nigeria. Clin Microbiol 6: 285. doi:10.4172/2329-8847.1000285

Page 2 of 6

From the random spot urine samples collected, spot urine creatinine (SUCr) was performed. Also from the $24 \mathrm{~h}$ urine samples collected, $24 \mathrm{~h}$ urine creatinine $(24 \mathrm{HUCr})$ and $24 \mathrm{~h}$ urine protein (24HUP) were performed. Hemoglobin (Hb), CD4 cells count and serum creatinine were performed on the blood samples collected. Other tests done from the blood samples were HIV screening and confirmatory tests. Creatinine was determined by modified Jeff's method and protein by photometric method. Creatinine clearance $(\mathrm{ClCr})$ was determined $[8,14-16]$.

\section{Statistical analyses}

The data were analyzed using SPSS version 17.0 (SPSS Int. Chicago, II, USA). The distribution and characterization of BMI, $\mathrm{Hb} 24 \mathrm{HUCr}$ and $\mathrm{ClCr}$ among the subjects with different levels of CD4 cells count were analyzed using cross-tabulation. For continuous variables, mean values and standard deviations were calculated and the means compared using ANOVA or two sample t-test. Categorical variables were compared using the nonparametric tests - Chi-squares. Multivariate linear regression analyses were used to determine the strength of variables to predict CD4 200-349 cells/ml, CD4 350-499 cells $/ \mathrm{ml}$ and CD4 $\geq 500$ cells $/ \mathrm{ml}$. All the tests were two-tailed and $\mathrm{p} \leq$ 0.05 was taken as statistically significant $[8,14,17,18]$. The potential risk factors of different levels of $<$ CD4 500 cells $/ \mathrm{ml}$ evaluated were BMI, 24HUCr, 24HUP, $\mathrm{ClCr}$, and $\mathrm{Hb}$.

\section{Definition of terms}

Mild immunosuppression: CD4 350-499 cells/ml

Moderate immunosuppression: CD4 200-349 cells/ml

Severe immunosuppression: CD $4<200$ cells $/ \mathrm{ml}$

WHO classification was used to define BMI levels as follows: $[8,14,19]$

\section{Underweight $=\mathrm{BMI}<18.5 \mathrm{~kg} / \mathrm{m}^{2}$}

Normal weight=BMI $18.5-24.9 \mathrm{~kg} / \mathrm{m}^{2}$

Overweight=BMI $25.0-29.9 \mathrm{~kg} / \mathrm{m}^{2}$

Obesity class I=BMI $30.0-34.9 \mathrm{~kg} / \mathrm{m}^{2}$

Obesity class II=BMI $35.0-39.9 \mathrm{~kg} / \mathrm{m}^{2}$

Obesity class III $=$ BMI $\geq 40.0 \mathrm{~kg} / \mathrm{m}^{2}$

However, in this study, obesity was defined as class I, class II and class III obesity added together.

Anemia was defined according to the WHO criteria $[8,14,20,21]$.

No anemia: $\mathrm{Hb}>13.0 \mathrm{~g} / \mathrm{dl}$ in males and $\mathrm{Hb}>12.0 \mathrm{~g} / \mathrm{dl}$ in females.

Mild anemia: $\mathrm{Hb} 11.0-13.0 \mathrm{~g} / \mathrm{dl}$ in males and $\mathrm{Hb} 11.0-12.0 \mathrm{~g} / \mathrm{dl}$ in females.
Moderate anemia: $\mathrm{Hb} 8.0-10.9 \mathrm{~g} / \mathrm{dl}$ in males and $\mathrm{Hb} 8.0-10.9 \mathrm{~g} / \mathrm{dl}$ in females.

Severe anemia: $\mathrm{Hb}<8.0 \mathrm{~g} / \mathrm{dl}$ in males and $\mathrm{Hb}<8.0 \mathrm{~g} / \mathrm{dl}$ in females.

However, in this study, anemia was defined as $\mathrm{Hb}<13.0 .0 \mathrm{~g} / \mathrm{dl}$ in males and $\mathrm{Hb}<12.0 \mathrm{~g} / \mathrm{dl}$ in females. Overall, in this study, anemia was defined as $\mathrm{Hb} \leq 12.0 \mathrm{~g} / \mathrm{dl}$.

\section{Results}

In the subjects studied, majority (97.0\%) were Igbos; females constituted $72.0 \%$. Their mean age was $39+11$ years. CD4 200-349 cells/ml was observed in 123 (31.3\%\%), CD4 350-499 cells/ml in 100 (25.4\%) and CD4 $\geq 500 \mathrm{cells} / \mathrm{ml}$ in $122(31.0 \%)$. The mean values of the variables were $26.2 \pm 5.4 \mathrm{mg} / \mathrm{kgm}^{2}, 11.2 \pm 1.8 \mathrm{~g} / \mathrm{dl}, 1507 \pm 781 \mathrm{mg}$ and $91.42 \pm 22.98 \mathrm{mls} / \mathrm{min}$ for $\mathrm{BMI}, \mathrm{Hb}, 24 \mathrm{HUCr}$ and $\mathrm{ClCr}$ respectively.

Among those who were underweight $\left(\mathrm{BMI}<18.5 \mathrm{~kg} / \mathrm{m}^{2}\right)$ the prevalence of $\mathrm{CD} 4<200$ cells $/ \mathrm{ml}$ of $4.2 \%$ was significantly low compared to CD4 $\geq 500$ cells $/ \mathrm{ml}$ of $25.0 \%$, and CD4 200-349 cells $/ \mathrm{ml}$ of $50.0 \%$. Overall, CD4 cells $/ \mathrm{mml}<500$ cells $/ \mathrm{ml}$, observed in $75.0 \%$ of all those who were underweight was significantly high $(\mathrm{df}=9, \mathrm{p}=0.008)$ (Figure 1 and Table 1).

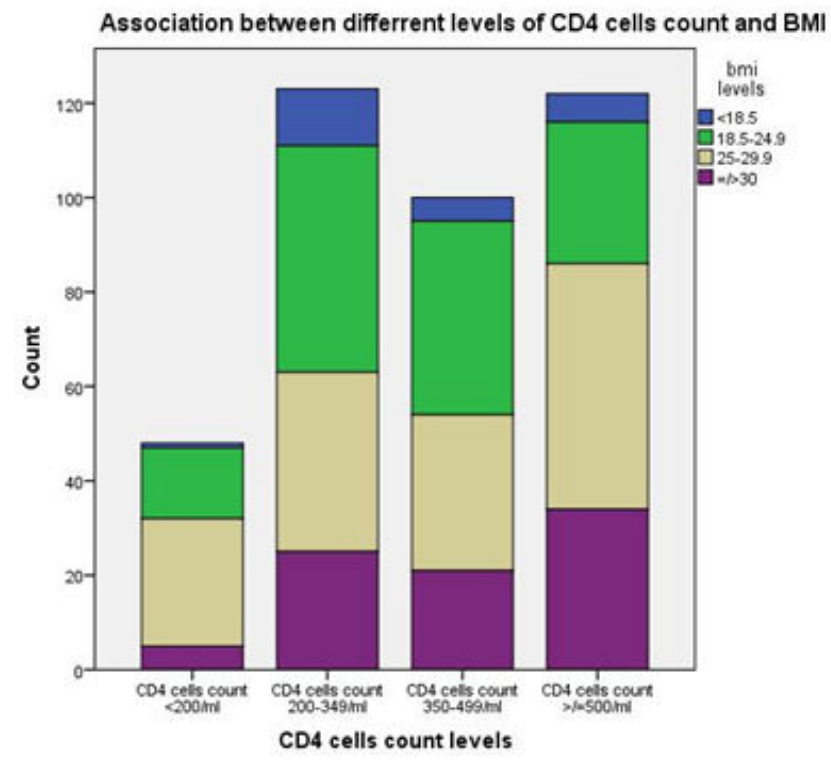

Figure 1: Association between different levels of CD4 cells count and BMI.

\begin{tabular}{|c|c|c|c|c|c|c|c|c|}
\hline \multirow{2}{*}{ Variables } & \multicolumn{4}{|c|}{ CD4 cells count levels (cells/ml) (no/\%) } & \multirow[t]{2}{*}{$\wedge 2$} & \multirow[t]{2}{*}{ Df } & \multirow[t]{2}{*}{ LHR } & \multirow{2}{*}{$P$ value } \\
\hline & $<200$ & 200-349 & $350-499$ & $\geq 500$ & & & & \\
\hline BMI $\left(\mathrm{kg} / \mathrm{m}^{2}\right)<18.5$ & $1(4.2 \%)$ & $12(50.0 \%)$ & $5(20.8 \%)$ & $6(25.0 \%)$ & 22.311 & 9 & 0.007 & 0.008 \\
\hline $18.5-24.9$ & $15(11.2 \%)$ & $48(35.8 \%)$ & $41(30.6 \%)$ & $30(22.4 \%)$ & & & & \\
\hline 25.0-29.9 & $27(18.0 \%)$ & $38(25.3 \%)$ & $33(22.0 \%)$ & $52(34.7 \%)$ & & & & \\
\hline
\end{tabular}


Citation: Anyabolu EN (2017) Variable Influencing Parameters of Different Levels of Immunosuppression in HAART-naive HIV Subjects in Nigeria. Clin Microbiol 6: 285. doi:10.4172/2329-8847.1000285

Page 3 of 6

\begin{tabular}{|c|c|c|c|c|c|c|c|c|}
\hline$\geq 30$ & $5(5.9 \%)$ & $25(29.4 \%)$ & $21(24.7 \%)$ & $34(40.0 \%)$ & & & & \\
\hline $\begin{array}{l}24 \mathrm{HUCr} \\
<300 \mathrm{mg}\end{array}$ & $0(0.0 \%)$ & $0(0.05)$ & $0(0.0 \%)$ & $2(100 \%)$ & 15.111 & 6 & 0.002 & 0.007 \\
\hline $300-3000 \mathrm{mg}$ & $40(11.5 \%)$ & $110(31.5 \%)$ & $98(28.1 \%)$ & $110(28.9 \%)$ & & & & \\
\hline$>1=3000$ & $4(16.7 \%)$ & $8(33.3 \%)$ & $0(0.0 \%)$ & $12(50.0 \%)$ & & & & \\
\hline $\begin{array}{l}\mathrm{Hb}(\mathrm{g} / \mathrm{dl}) \\
\geq 12.0\end{array}$ & $9(7.1 \%)$ & $37(29.1 \%)$ & $23(18.1 \%)$ & $58(45.7 \%)$ & 31.683 & 9 & $<0.001$ & $<0.001$ \\
\hline $10.0-11.9$ & $29(16.3 \%)$ & $51(28.7 \%)$ & $55(30.9 \%)$ & $43(24.2 \%)$ & & & & \\
\hline $7.0-9.9$ & $8(9.8 \%)$ & $35(42.7 \%)$ & $20(24.4 \%)$ & $19(23.2 \%)$ & & & & \\
\hline$<7.0$ & $2(33.3 \%)$ & $0(0.0 \%)$ & $2(33.3 \%)$ & $2(33.3 \%)$ & & & & \\
\hline
\end{tabular}

Table 1: Distribution and characterization of variables at different levels of CD4 cells count in study subjects $(n=393)$.

Among those whose weight were normal (BMI 18.5-24.9 kg/m²), the prevalence of CD4 $\geq 500$ cells $/ \mathrm{ml}$ of $22.4 \%$ was significantly low compared to those who have CD4 350-499 cells/ml of 30.6\% and CD4 200-349 cells $/ \mathrm{ml}$ of $35.8 \%(\mathrm{df}=\mathrm{xx}, \mathrm{p}=0 . \mathrm{xx})$. However, $\mathrm{CD} 4<200 \mathrm{cells} / \mathrm{ml}$ was observed in $11.2 \%$, a very low prevalence among this group with normal weight. Similar results were observed in those who were overweight (BMI 25.0-29.9 kg/m²) (Figure 1 and Table 1).

Twenty-four-hour urine creatinine $<300 \mathrm{mg}$ was observed only in those who have $\mathrm{CD} 4 \geq 500$ cells $/ \mathrm{ml}$, demonstrating that dilute urine was significantly absent in those who have depressed immunity $(\mathrm{df}=6$, $\mathrm{p}=0.019$ ). Among those who have $24 \mathrm{HUCr} 300-3000 \mathrm{mg}$, the prevalence of $\mathrm{CD} 4<200$ cells $/ \mathrm{ml}$ of $11.5 \%$ was significantly low compared to $31.5 \%$ and $28.1 \%$ in those with CD4 200-349 cells $/ \mathrm{ml}$ and CD4 350-499 cells $/ \mathrm{ml}$ respectively, $\mathrm{df}=6, \mathrm{p}=0.019$. Furthermore, the prevalence of CD4 $\geq 500$ cells $/ \mathrm{ml}$ of $50.0 \%$ observed in those whose $24 \mathrm{HUCr}$ was $>3000 \mathrm{mg}$ was high compared to $16.7 \%$ for CD4 $<200$ cells $/ \mathrm{ml}, 33.3 \%$ for CD4 200-349 cells $/ \mathrm{ml}$ and $0.0 \%$ for CD4 350-499 cells $/ \mathrm{ml}$. This however, demonstrated that immunosuppression declined as $24 \mathrm{HUCr}$ declined (Figure 2 and Table 1).

In the subjects whose $\mathrm{Hb}$ were normal $(>12.0 \mathrm{~g} / \mathrm{dl})$, the prevalence of CD4<200 cells $/ \mathrm{ml}$ of $7.1 \%$ was significantly low compared to $29.1 \%$ and $18.1 \%$ for those who have CD4 200-349 cells/ml and CD4 350-499 cells $/ \mathrm{ml}$ respectively $(\mathrm{df}=9, \mathrm{p} \leq 0.001)$, indicating a low level of intense immunosuppression among those whose $\mathrm{Hb}$ were normal. In contrast, the prevalence of CD4 $\geq 500$ cells $/ \mathrm{ml}$ declined as $\mathrm{Hb}$ declined, $24.2 \%$ in Hb10.0-12.0 g/dl and 23.2\% in Hb7.0-9.9 g/dl. Observed also was a significantly high prevalence $(28.3 \%$ and $42.7 \%$ respectively) of CD 4 cells $200-349 / \mathrm{ml}$ and CD4 cells 350-499/ml, among those who have $\mathrm{Hb}$ $10-12.0 \mathrm{~g} / \mathrm{dl}$ and $\mathrm{Hb} 7.0-9.9 \mathrm{~g} / \mathrm{dl}$ compared to those with $\mathrm{CD} 4<200$ cells/ml. A similar pattern was observed with CD4 350-499 and $\mathrm{Hb} 10-12, \mathrm{Hb}$ 7-9.9. This showed that progressive decline in immunity was significantly associated with worsening anemia, but those with the lowest immunity, however, did not have the highest prevalence of anemia (Figure 3 and Table 2).

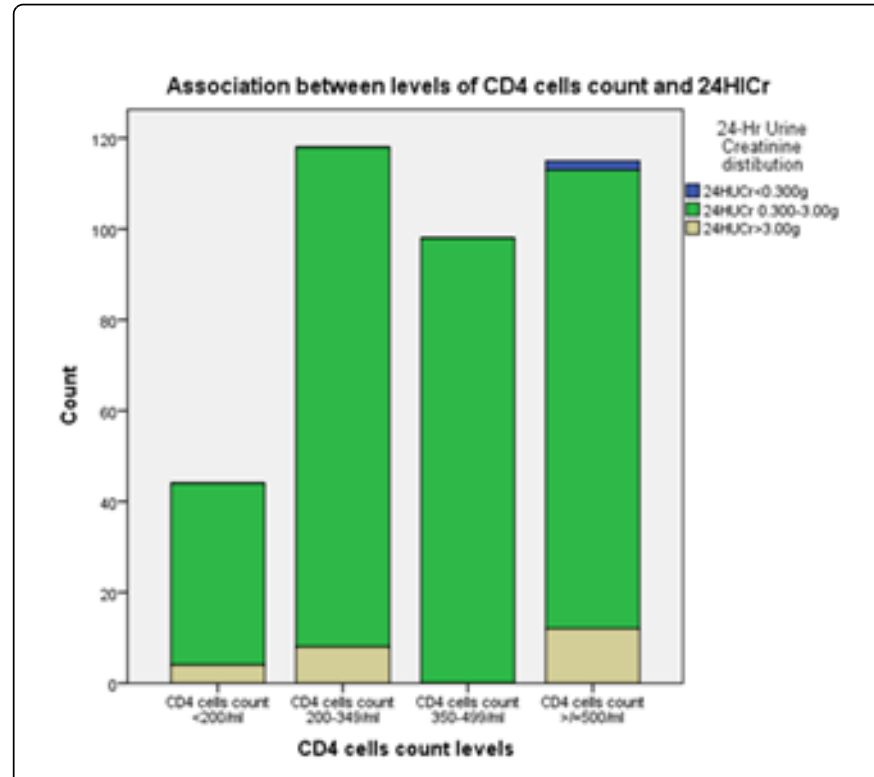

Figure 2: Association between levels of $\mathrm{CD} 4$ cells count and $24 \mathrm{HUCr}$.

Significant but poor correlation was observed between CD4 cells count and BMI ( $\mathrm{r}=0.122, \mathrm{p}=0.015), \mathrm{Hb}(\mathrm{r}=-0.153, \mathrm{p}=0.002), \mathrm{ClCr}$ $(\mathrm{r}=-0.122, \mathrm{p}=0.018)$ as well as 24HUP $(\mathrm{r}=-0.117, \mathrm{p}=0.023)$. However, the correlation between CD4 cells count and $24 \mathrm{HUCr}$ was not significant, $(r=-0.007, \mathrm{p}=0.896)$.

Multivariate linear regression analyses showed that none of these variables studied predicted CD4 200-349 cells/ml, whereas CD4 $350-499$ cells $/ \mathrm{ml}$ was predicted by BMI $(\mathrm{p}=0.006), \mathrm{ClCr}(\mathrm{p}=0.008)$, 24HUP ( $\mathrm{p}=0.026)$ and $\mathrm{Hb}(\mathrm{p}=0.003)$ (Tables 2-4). In contrast, $\mathrm{Hb}$ and $24 \mathrm{HUP}$ predicted $\mathrm{CD} 4>500$ cells $/ \mathrm{ml} \quad(\mathrm{p}=0.013$ and $\mathrm{p}=0.008$ respectively). 
Page 4 of 6

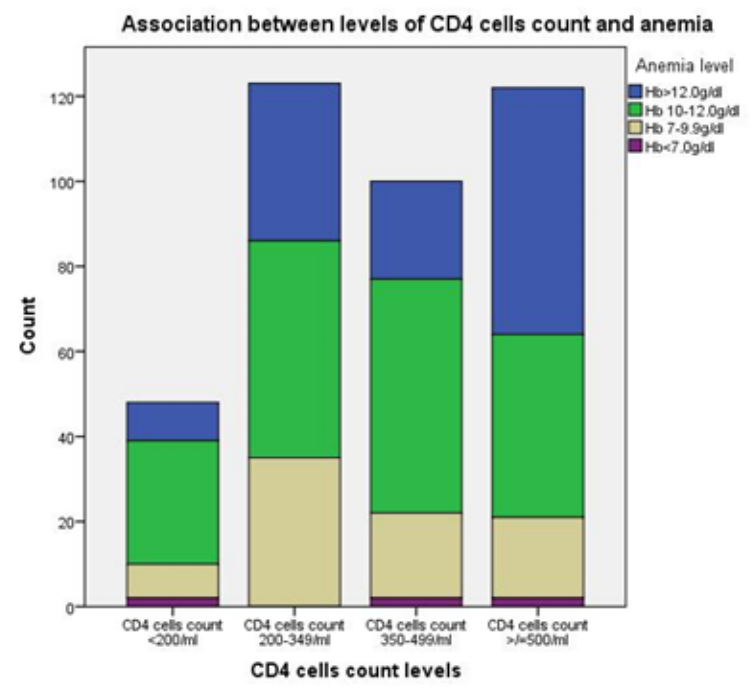

Figure 3: Association between levels of CD4 cells count and anemia.

\begin{tabular}{|l|l|l|l|l|}
\hline Variables & Beta & $\mathbf{T}$ & $\mathbf{P}$ value & $\mathbf{9 5 \%} \mathrm{Cl}$ \\
\hline Body mass index & -0.183 & -1.24 & 0.926 & $-1.519-1.667$ \\
\hline $\begin{array}{l}24 \mathrm{~h} \\
\text { creatinine }\end{array}$ & 0.069 & 0.694 & 0.489 & $-6.906-14.358$ \\
\hline Hemoglobin & 0.189 & 1.8 & 0.075 & $-0.484-10.06$ \\
\hline $\begin{array}{l}\text { Creatinine } \\
\text { clearance }\end{array}$ & -0.166 & -1.806 & 0.073 & $-0.633-0.03$ \\
\hline 24HUP & 0.116 & 1.224 & 0.223 & $-7.053-29.855$ \\
\hline
\end{tabular}

$\mathrm{Cl}=$ Confidence Interval, $\mathrm{R} 2=0.075, \mathrm{df}=5, \mathrm{p}=0.114$

Table 2: Multivariate linear regression of variables with CD4 cells count (200-349 cells/ml) in study subjects $(\mathrm{n}=123)$.

\begin{tabular}{|l|l|l|l|l|}
\hline Variables & Beta & $\mathbf{T}$ & $\mathbf{P}$ value & $\mathbf{9 5 \%} \mathbf{C l}$ \\
\hline $\begin{array}{l}\text { Body mass } \\
\text { index }\end{array}$ & 0.275 & 2.444 & 0.016 & $0.404-3.915$ \\
\hline $\begin{array}{l}24 \mathrm{~h} \text { urine } \\
\text { creatinine }\end{array}$ & -0.089 & -0.863 & 0.39 & -9.844 \\
\hline Hemoglobin & -0.289 & -2.553 & 0.012 & -0.662 \\
\hline $\begin{array}{l}\text { Creatinine } \\
\text { clearance }\end{array}$ & -0.224 & -2.155 & 0.034 & -0.662 \\
\hline 24HUP & 0.216 & 2.27 & 0.026 & $7.548-113.260$ \\
\hline
\end{tabular}

$\mathrm{Cl}=$ Confidence Interval, $\mathrm{R} 2=0.203, \mathrm{df}=5, \mathrm{p}=0.001$

Table 3: Multivariate linear regression of variables with CD4 cells count 350-499 cells/ $\mathrm{ml}$ in study subjects $(\mathrm{n}=100)$.

\section{Discussion}

Variable prevalence $31.3 \%$, and $25.4 \%$ for CD4 200-349 cells $/ \mathrm{ml}$, CD4 350-499 cells $/ \mathrm{ml}$ respectively observed in HIV subjects in this study were higher than the prevalence value of $11.2 \%$ for $C D 4<200$ cells/ml reported by Anyabolu [8]. Together, both the Anyabolu study and this study show that in the spectrum of immunosuppression in HIV subjects, stepwise declining immunity was not unidirectional. Like any other Gaussian system, those who have moderate immunosuppression (CD4 200-349 cells/ml) peaked in prevalence, trailed by those who have mild immunosuppression (CD4 350-499 cells $/ \mathrm{ml}$ ) and those who have severe immunosuppression $(\mathrm{CD} 4<200$ cells $/ \mathrm{ml}$ ), as is demonstrated in this study.

\begin{tabular}{|l|l|l|l|l|}
\hline Variables & Beta & $\mathbf{T}$ & $\mathbf{P}$ value & $\mathbf{9 5 \%} \mathrm{Cl}$ \\
\hline Body mass index & -0.104 & -1.113 & 0.268 & $-7.022-1.971$ \\
\hline $\begin{array}{l}24 \mathrm{~h} \text { urine } \\
\text { creatinine }\end{array}$ & 0.096 & 1.058 & 0.296 & $-13.916-45.790$ \\
\hline Hemoglobin & 0.226 & 2.523 & 0.013 & $3.705-30.860$ \\
\hline $\begin{array}{l}\text { Creatinine } \\
\text { clearance }\end{array}$ & -0.131 & -1.461 & 0.147 & $-2.033-0.307$ \\
\hline 24HUP & -0.251 & -2.719 & 0.008 & -348.958 \\
\hline Cl=Confidence Interval, R2 $=0.143, \mathrm{df}=5, \mathrm{p}=0.005$. \\
\hline
\end{tabular}

Table 4: Multivariate linear regression of variables with CD4 cells count $\geq 500$ cells $/ \mathrm{ml}$ in study subjects $(\mathrm{n}=122)$.

In this study, majority (75.0\%) of those who were underweight have $\mathrm{CD} 4<500$ cells $/ \mathrm{ml}$. In these underweight subjects who have immunosuppression, the prevalence of moderate immunosuppression (50.0\%) was high compared to mild immunosuppression $(2.8 \%)$ and severe immunosuppression (4.2\%). Studies have shown an association between low CD4 cells count and underweight $[8,22]$, but they did not evaluate the association CD4 might have with the different levels of immunosuppression, unlike this study. Declining weight is associated with infections and malnutrition in HIV subjects, especially in the developing nations [23]. However, this association is variable as shown in this study.

This study also shows that in obese HIV subjects, moderate immunosuppression (CD4 200-349 cells/ml) was high (29.4\%), compared to mild (24.7\%) and severe (5.9\%). Obesity has been associated with immunosuppression, as shown in one study [8]. However, this study showed a Gaussian distribution of obesity with immunosuppression, peaking with moderate immunosuppression, and declining with mild and severe immunosuppression. It was also shown, in this study, that BMI predicted mild, but not moderate, immunosuppression, indicating a variable association between BMI and different levels of immunosuppression.

In this study, it was demonstrated that dilute urine [23] was significantly absent in the subjects who have reduced immunity, and further showed reduced urine concentration [23] in these immunosuppressed subjects, more pronounced among those who have moderate immunosuppression (33.3\%), compared to those whose immunosuppression was mild $(0.0 \%)$ and those severe $(16.7 \%)$. This observation demonstrated that the ability to concentrate urine was not impaired by the degree of immunosuppression in these subjects. From literature search, there was a paucity of studies on the effects of levels 
Page 5 of 6

of immunosuppression on urine dilution and concentration. In one study, an association was demonstrated between urine creatinine and CD4 cells count, but like the second study by the same author, this association did not assess these effects at different levels of immunosuppression $[8,23]$. Nonetheless, some disease states, including those of the pituitary and kidneys may cause abnormalities of urine dilution and urine concentration [24].

This study showed that progressive decline in immunity was significantly associated with worsening anemia, but observed that those who have the lowest immunity, however, did not have the highest prevalence of anemia. Although a study has shown an association between low CD4 cells and anemia, it did not evaluate the different levels of immunosuppression, unlike this study [8]. Anemia is often associated with HIV disease progression, compounded by opportunistic infections and malnutrition [25]. Expectedly, anemia should increase as immunosuppression increases. This was not observed in this study.

In this study, $\mathrm{ClCr}, 24 \mathrm{HUP}$ and $\mathrm{Hb}$ were found to be predictors of mild immunosuppression (CD4 350-499 cells $/ \mathrm{ml}$ ). A study found an association between low $\mathrm{CD} 4<200$ cells/ml severe immunosuppression and $\mathrm{ClCr}$ as well as 24HUP [8]. However, the study did not assess CD4 different levels, differing from this study. Renal diseases are common in HIV infection and tend to increase with HIV disease progression, influenced by different levels of immunosuppression [15,26]. However, this study has demonstrated variable association between proteinuric renal damage and different levels of immunosuppression.

This study, overall, has shown that the association between different degrees of immunosuppression and abnormal weight, proteinuric renal damage as well as anemia was variable. Contrary to assumptions, these did not altogether increase with declining immunity.

Stakeholders involved in the management of HIV infection and its complications [27] should evaluate HIV subjects sequentially, on follow-up, for immunosuppression, determined by CD4 cells count, and search for anemia, abnormal weight and renal damage in those who have depressed immunity, irrespective of the degree of this immunosuppression [8].

\section{Conclusion}

Variable levels of immunosuppression were prevalent in this study. Anemia, renal damage and abnormal weight were common but variable at different levels of immunosuppression in HIV subjects in the early stage of the infection. There is a need for clinicians to assess immunosuppression in routine HIV clinical practice and to further search for abnormal weight, anemia and renal damage in those who have CD4 cells count $<5000$, with greater attention as CD4 cells count declines.

\section{Limitation}

An assessment of absolute HIV viral load was not done but would have added color to this study if it was evaluated. Further analyses of CD4 0-99 cells $/ \mathrm{ml}$ and 100-199 cells/ml would have been of immense value, if they were included.

\section{What is already known about this topic:}

A: The prevalence of low $\mathrm{CD} 4$ cells count is high in treatment-naïve HIV subjects;
B: Abnormal weight, dyslipidemia and proteinuric renal damage were common among treatment-naïve HIV subjects who have low CD4 cells count;

C: Influencing parameters of different levels of immunosuppression have not been completely identified.

\section{What this study adds to knowledge:}

A: Variable degrees of immunosuppression are prevalent in treatment-naïve HIV subjects.

B: Anemia, renal damage and abnormal weight are common but variable at different levels of immunosuppression in HIV subjects in the early stage of the infection.

C: HIV subjects who have the highest immunosuppression did not have the highest degree of anemia or renal damage.

\section{References}

1. Akinwande O, Ogundiran T, Akarolo SA, Mamadu I, Dakum P, et al. (2009) Challenges in Treating Malignancies in HIV in Nigeria. Curr Opin Oncol 21: 455-461.

2. Ramírez BC, Vega YC, Shepherd BE, Grinsztejn B, Wolff M, et al. (2016) Time to HAART Initiation after Diagnosis and Treatment of Opportunistic Infections in Patients with AIDS in Latin America. PLOS One 11.

3. Mhozya H, Bintabara D, Kibusi S, Neilson E, Mpondo BC (2015) Latestage disease at presentation to an HIV clinic in eastern Tanzania: A retrospective cross-sectional study. Malawi Med J 27: 125-127.

4. Fantin B, Joly V, Elbim C, Golmard JL, Pocidalo MA, et al. (1996) Lymphocyte subset counts during the course of community-acquired pneumonia: evolution according to age, human immunodeficiency virus status, and etiologic microorganisms. Clin Infect Dis 22: 1096-1098.

5. Aldrich J, Gross R, Adler M, King K, MacGregor RR, et al. (2000) The effect of acute severe illness on CD4+ lymphocyte counts in nonimmunocompromised patients. Arch Intern Med. 160: 715-716.

6. Okoye AA, Picker LJ (2013) CD4+ T cell depletion in HIV infection:mechanisms of immunological failure. Immunol Rev. 254: 54-64.

7. Mellors JW, Munoz A, Giorgi JV, Margolick JB, Tassoni CJ, et al. (1997) Plasma viral load and CD4+ lymphocytes as prognostic markers of HIV-1 infection. Ann Intern Med 126: 946-954.

8. Anyabolu EN (2017) Factors of Low CD4 Cells Count in Treatment-naïve HIV Subjects in Southeast Nigeria. J AIDS Clin Res 8: 668.

9. Messele T, Wit RTF, Brouwer M, et al. (2001) No difference in in vitro susceptibility to HIV type 1 between high-risk HIV-negative Ethiopian commercial sex workers and low-risk control subjects. AIDS Res Hum Retroviruses 17: 433-441.

10. Tollerud DJ, Clark JW, Brown LM, Neuland CY, Trost LK, et al. (1989) The influence of age, race, and gender on peripheral blood mononuclearcell subsets in healthy nonsmokers. J Clin Immunol 9: 214-222.

11. Mair C, Hawes SE, Agne HD, Sow PS, N'doye I, et al. (2008) Factors associated with CD4 lymphocyte counts in HIV-negative Senegalese individuals. Clin Exp Immunol 151: 432-440.

12. Blattner W, Dakum P, Osotimehin B, Nasidi A, Abimiku A (2008) Public Health Aspects of HIV/AIDS - Nigeria and West Africa. Springer pp. 217- 251 .

13. Federal Republic of Nigeria Global AIDS Response and Progress Report 2012.

14. Anyabolu EN (2017) Low Density Lipoprotein Cholesterol in a General Out-patient Population in a Tertiary Hospital in Southeast Nigeria: Associations and Implications. Clin Med Diag 7: 8-17.

15. Anyabolu EN, Chukwuonye II, Arodiwe E, Ijoma CK, Ulasi I (2016) Prevalence and predictors of chronic kidney disease in newly diagnosed 
Citation: Anyabolu EN (2017) Variable Influencing Parameters of Different Levels of Immunosuppression in HAART-naive HIV Subjects in Nigeria. Clin Microbiol 6: 285. doi:10.4172/2329-8847.1000285

Page 6 of 6

human immunodeficiency virus patients in Owerri, Nigeria. Indian J Nephrol 26: 10-15.

16. Anyabolu EN, Chukwuonye II, Mabayoje M, Ejike A, Ijoma CK, et al. (2015) Comparison of Spot Urine Protein/Creatinine Ratio, Spot Urine Protein/Osmolality Ratio with Measured 24-Hour Urine Protein in HIV Subjects in Nigeria. J AIDS Clin Res 6: 445.

17. Anyabolu EN (2016) BMI and Risk Factors of Underweight and Obesity in HIV Subjects in Eastern Nigeria. J AIDS Clin Res 6: 8-15.

18. Anyabolu EN (2016) Body Mass Index and Associated Factors of Obesity and Underweight in a General Out-patient Population in a Tertiary Hospital in Nigeria. Am J Int Med 4(5): 85-92.

19. WHO (1995) Physical Status: The Use and Interpretation of Anthropometry. Technical Report Series 854, 1-1-9950. World Health Organization, Geneva. Available at http://www.who.int/childgrowth/ publications/physical_status/en/ Accessed on 29/10/2016.

20. Hemoglobin concentrations for the diagnosis of anemia and assessment of severity VMNIS | Vitamin and Mineral Nutrition Information System WHO/NMH/NHD/MNM/11.1. Available at http://www.who.int/vmnis/ indicators/haemoglobin/en/ Accessed on 29/10/2016.

21. Ernest Anyabolu (2016) Prevalence and Associated Factors of Anemia in Treatment-naïve HIV-positive Subjects in Southeast Nigeria. Am J Med Sci Medicine 4: 241-246.
22. Cianflone NFC, Roediger M, Lynn E, Eberly, Ganesan A, et al. (2011) Impact of Weight on Immune Cell Counts among HIV-Infected Persons. Clin Vaccine Immunol 18: 940-946.

23. Anyabolu EN (2016) Urine creatinine in treatment-naïve HIV subjects in eastern Nigeria. Pan Afr Med J 25: 139.

24. Yeh HC, Lin YS, Kuo CC, Weidemann D, Weaver V, et al. (2015) Urine osmolality in the US population: implications for environmental biomonitoring. Environ Res 136: 482-490.

25. Asfaw M, Wondaferash M, Taha M, Dube L (2015) Prevalence of undernutrition and associated factors among children aged between six to fifty-nine months in Bule Hora district, South Ethiopia. BMC Public Health. 15: 41

26. Phair J, Palella F (2011) Renal disease in HIV infected Individuals. Curr Opin HIV AIDS 6: 285-289.

27. Ciccone MM, Aquilino A, Cortese F, Scicchitano P, Sassara M, et al. (2010) Feasibility and effectiveness of a disease and care management model in the primary health care system for patients with heart failure and diabetes (Project Leonardo). Vasc Health Risk Manag. 6: 297-305. 